\title{
Antibacterial activity of gold nanoparticles and their toxicity assessment
}

\author{
K Umamaheswari ${ }^{1 *}$, R Baskar $^{1}$, K Chandru $^{3}$, N Rajendiran ${ }^{2}$, S Chandirasekar ${ }^{2}$ \\ From 2nd International Science Symposium on HIV and Infectious Diseases (HIV SCIENCE 2014) \\ Chennai, India. 30 January - 1 February 2014
}

\section{Background}

Several classes of antimicrobial nanoparticles (NPs) and nanosized carriers for antibiotics delivery have proved their effectiveness as alternative agents to combat the antimicrobial resistance experienced with conventional drugs. Gold nanostructures find extensive applications in nano electronics and nanomedicine.

\section{Methods}

The present study involved the synthesis of gold nanoparticles using a sodium cholate, as both reducing and capping agent and characterization by UV-Visible spectroscopy and High ResolutionTransmission Electron Microscopy (HRTEM). The antibacterial activity on significant bacterial species was evaluated by micro broth dilution method. The mechanism for antibacterial action of the gold nanoparticles were studied by reactive oxygen species (ROS) generation that causes oxidative stress to microbial cells and release of intracellular enzyme lactate dehydrogenase into extracellular medium (LDH assay) indicative of loss of cell membrane integrity.

\section{Results}

The synthesized gold nanoparticles showed characteristic peak at $541 \mathrm{~nm}$ by UV-Visible spectroscopy with particle size of $10 \mathrm{~nm}$ as confirmed by HRTEM. The minimum inhibitory concentration $\left(\mathrm{MIC}_{80}\right)$ of the nanoparticles on E. coli, S. typhi, P. aeruginosa, K. pneumoniae, ranged from 20 to $40 \mu \mathrm{g} / \mathrm{mL}$. The ROS generation was directly dependent on the concentration of the nanoparticles and no detectable enzyme leakage was recorded.

\footnotetext{
* Correspondence: rk_uma@yahoo.com

'Department of Biotechnology, University of Madras, Guindy, Chennai, India Full list of author information is available at the end of the article
}

\section{Conclusion}

The results showed appreciable antibacterial activity of gold nanoparticles against the tested species and the possible mechanism of antibacterial activity may be due to increased intracellular ROS generation causing oxidative stress to the bacterial cells while LDH assay indicated that nanoparticles caused no damage to the cell membrane integrity.

\section{Authors' details}

'Department of Biotechnology, University of Madras, Guindy, Chennai, India. ${ }^{2}$ Department of Polymer Science, University of Madras, Guindy, Chennai, India. ${ }^{3}$ Centre for Biotechnology, Anna University, Guindy, Chennai, India.

Published: 27 May 2014

doi:10.1186/1471-2334-14-S3-P64

Cite this article as: Umamaheswari et al:: Antibacterial activity of gold nanoparticles and their toxicity assessment. BMC Infectious Diseases 2014 14(Suppl 3):P64.

\author{
Submit your next manuscript to BioMed Central \\ and take full advantage of: \\ - Convenient online submission \\ - Thorough peer review \\ - No space constraints or color figure charges \\ - Immediate publication on acceptance \\ - Inclusion in PubMed, CAS, Scopus and Google Scholar \\ - Research which is freely available for redistribution \\ Submit your manuscript at \\ www.biomedcentral.com/submit
}

